\title{
Editor's Report for Volume 119 (2005)
}

Mailing dates for issues in volume 119: (1) 6 June 2006, (2) 13 June 2006, (3) 30 November 2006, (4) 17 April 2007. A summary of membership and subscriber totals 2004 is given in Table 1 . The number of articles and notes in volume 119 is summarized in Table 2 by topic; totals for Book Reviews and New Titles are given in Table 3 , and the distribution of content by page totals per issue in Table 4 .

Council continued to authorize $40 \%$ of membership dues for publication of the journal and all of subscriptions (both individual and institutional). Council also has allocated $80 \%$ of the annual interest from the Manning Fund and other capital funds to The Canadian Field-Naturalist. Use of the Manning fund portion was broadened on an issue-by-issue basis to offset the publication costs where author and institutional contributions were insufficient to cover page charges.

The journal was printed at Gilmore Printers, Ottawa, and thanks are due business representative Tom Smith, customer representative Chuck Graham for overseeing production, and Wendy Cotie for typesetting and corrections. Leslie Cody prepared the Index for volume 119; Elizabeth Morton proofed the galleys. Long-time (60 years) Business Manager for the journal, Bill Cody, gradually relinquished much of his active role during the year and some of his duties were shouldered by treasurer Frank Pope and assistant treasurer Jim Ward. Roy John processed books sent by publishers, assigned reviewers, edited book reviews and prepared the New Titles listing. Sandra Garland the Ottawa FieldNaturalists' Club webmaster, posted contents and abstracts from each issue as it appeared, and sent pdfs of articles and notes ordered by authors.

Manuscripts (excluding book reviews, notices, and reports) submitted to The Canadian Field-Naturalist totalled 75 in 2005 , equalling the total for 2004. The following reviewed papers submitted in 2005 (with number of manuscripts reviewed in parentheses if more than one):
TABLE 2. Number of articles and notes published in The Canadian Field-Naturalist Volume 119 (2005) by major field of study.

\begin{tabular}{lccr}
\hline \hline Subject & Articles & Notes & Total \\
\hline Mammals & 19 & 17 & 36 \\
Birds & 14 & 5 & 19 \\
Amphibians + reptiles & 2 & 1 & 3 \\
Fish & 6 & 1 & 7 \\
Invertebrates & 7 & 2 & 9 \\
Plants & 13 & 1 & 14 \\
Other & $1^{*}$ & 0 & 1 \\
\hline Totals & 62 & 27 & 89 \\
\hline \hline
\end{tabular}

\section{Associate Editors:}

R. Anderson, Canadian Museum of Nature, Ottawa, Ontario (2); C. D. Bird, Erskine, Alberta (9); R. R. Campbell, St. Albert, Ontario (3); P. M. Catling, Agriculture and Agrifood Canada, Ottawa (7); B. W. Coad, Canadian Museum of Nature, Ottawa (8); A. J. Erskine, Sackville, New Brunswick (12); D. F. McAlpine, New Brunswick Museum, Saint John, New Brunswick (9); D. W. Nagorsen, Mammalia Biological Consulting, Victoria, British Columbia (9); W. O. Pruitt, Jr., University of Manitoba, Winnipeg (16).

Additional Reviewers: W. B. Ballard, Texas Tech University, Lubbock, Texas (3); L. Bernatchez, Laval University, Quebec, Quebec; J. R. Bider, Baie o'Urfe, Quebec; G. Blouin-Demers, University of Ottawa, Ontario; D. Boyd, Helena, Montana; M. Brigham, University of Regina, Saskatchewan; L. Carbyn, Canadian Wildlife Service, Edmonton, Alberta (3); J. Cayouette, Agriculture and Agri-Food Canada, Ottawa; J. Cebek, Trent University, Peterborough, Ontario; T. Chubbs, Happy Valley - Goose Bay, Labrador, Newfoundland \& Labrador (3); H. D. Cluff, Resources, Wildlife \& Economic Development, Yellowknife, Northwest Territories (2); M. Crete, Ministre de l'Environment, Quebec, Quebec; A. W. Diamond, University of New Brunswick, Fredericton, New Brunswick (2); L. C. Dickamer, Northern Arizona University, Flagstaff, Arizona; P. Dobson, School of Veterinary Medicine, Philadelphia, Pennsylvania; J. Eger, Royal Ontario Museum, Tor-

TABLE 1. The 2005 circulation of The Canadian Field-Naturalist (2004 in parenthesis). Compiled by Robin Murphy, bmrgroup, Ottawa.

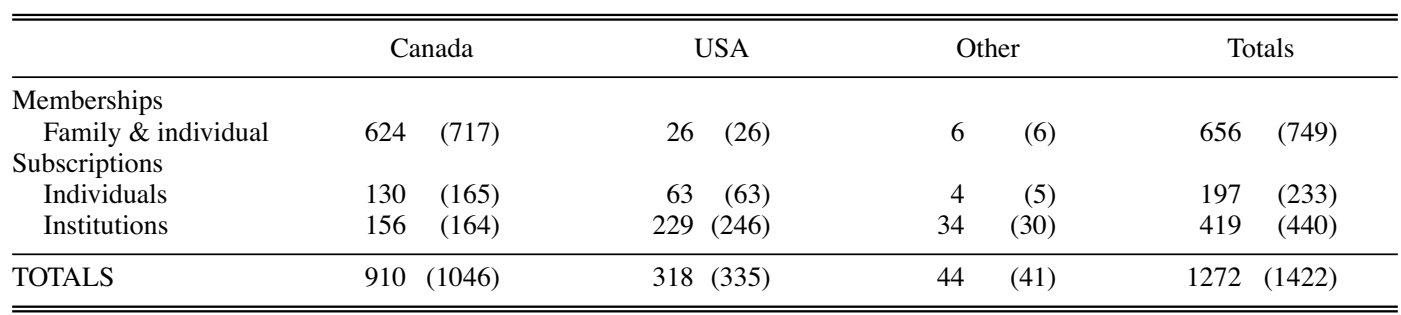

Note: 22 countries are included under "Other" (outside Canada and United States): Austria, Belgium, Brazil, Denmark (2), United Kingdom (9: including 1 to Scotland), Finland (2), France (3: including 1 to St. Pierre \& Miquelon), Germany (2), Iceland, Ireland, Japan, Mexico, Netherlands (3), New Zealand, Norway (4), Poland, Russia, South Africa, Spain (3), Sweden (2), Switzerland (2), Trinidad and Tobago. 
TABLE 3. Number of reviews and new titles published in Book Review section of The Canadian Field-Naturalist Volume 119 by topic.

\begin{tabular}{lcc}
\hline \hline & Reviews & New Titles \\
\hline Zoology & 33 & 104 \\
Botany & 5 & 19 \\
Environment & 17 & 10 \\
Miscellaneous & 6 & 20 \\
Young Naturalists & 0 & 2 \\
\hline Totals & 61 & 155 \\
\hline \hline
\end{tabular}

onto, Ontario; W. Foissner, Institut fur Zoologie, Salzburg, Austria; B. Freedman, Dalhousie University, Halifax, Nova Scotia; W. A. Fuller, Athabasca, Alberta; D. M. Green, Redpath Museum, McGill University, Montreal, Quebec (4); P. T. Gregory, University of Victoria, British Columbia (3); E. Haber, National Botanical Services, Ottawa, Ontario; F. H. Harrington, Mt. St. Vincent University, Halifax, Nova Scotia; V. L. Harms, University of Saskatchewan, Saskatoon; T. Haxton, Ministry of Natural Resources, Kemptville, Ontario (2); S. Herrero, University of Calgary, Alberta (2); G. Holroyd, Canadian Wildlife Service, Edmonton, Alberta; E. Holm, Royal Ontario Museum, Toronto; S. Hooker, University of St. Andrews, Fife, United Kingdom; C. S. Houston, Saskatoon, Saskatchewan; R. James, Sutherland, Ontario (2); M. Johnson, Game \& Fish Department, Bismarck, North Dakota; T. S. Jung, Environment, Fish and Wildlife Branch, Whitehorse, Yukon (2); R. W. Knapton, Edmonton, Alberta; K. Larsen, University College of the Cariboo, Kamloops, British Columbia; J. Lien, Memorial University of Newfoundland, St. John's; R. MacCulloch, Royal Ontario Museum, Toronto, Ontario; F. F. Mallory, Laurentian University, Sudbury, Ontario (2); J. Maunder, Pond Cove, Newfoundland (3); L. D. Mech, U.S. Geological Survey, The Raptor Center, University of Minnesota, St. Paul (3); R. Meisterfeld, Institute for Biology II (Zoology), Department of General Biology, Aachen; D. Naughton, Canadian Museum of Nature, Ottawa; J. S. Nelson, University of Alberta, Edmonton; J-P. Ouellet, Universite du Quebec a Rimouski; P. Paquet, Meacham, Saskatchewan (3); D. Paulson, Seattle, Washington; G. Parker, Canadian Wildlife Service, Sackville, New Brunswick; S. Petrie, Bird Studies Canada, Port Rowan, Ontario; G. Proulx, Alpha Research \& Management Ltd., Sherwood Park, Alberta (2); Raine, Golder Associates Ltd., Calgary, Alberta; R. Reeves, Okapi Wildlife Asso-
TABLE 4. Number of pages per section published in The Canadian Field-Naturalist Volume 119 (2005) by issue.

\begin{tabular}{lrrrrr}
\hline \hline & $(1)$ & $(2)$ & $(3)$ & $(4)$ & Total \\
\hline Articles & 128 & 132 & 118 & 95 & 473 \\
Notes & 12 & 8 & 21 & 16 & 57 \\
Book Reviews* $_{\text {CFN/OFNC Reports** }}^{* *}$ & 15 & 20 & 11 & 19 & 65 \\
News and Comment & 2 & 2 & 8 & 4 & 14 \\
Index & 0 & 0 & 0 & 32 & 32 \\
Advice to Contributors & 1 & 0 & 1 & 1 & 3 \\
\hline Totals & 158 & 164 & 160 & 168 & 650 \\
\hline \hline
\end{tabular}

* Total pages for book review section include both reviews and new titles listings.

** Includes CFN Editor's report in (2), OFNC Annual Business Meeting (3) and OFNC Awards (4).

ciates, Hudson, Quebec; J. D. Rising, University of Toronto, Ontario; L. Rogers, Ely, Minnesota; R. Rosatte, Ministry of Natural Resources, Trent University, Peterborough, Ontario; A. Russell, University of Calgary, Alberta; S. Sampson, Utah Museum of Natural History, Sault Lake City; Fred Scott, Acadia University, Wolfville, Nova Scotia; F. W. Schueler, Bishops Mills Natural History Center, Oxford Mills, Ontario (6); F. E. Schwab, College of the North Atlantic, Labrador City, Newfoundland and Labrador; D. Smith, Southern Connecticut State College, New Haven; K. W. Stewart, University of Manitoba, Winnipeg, Manitoba; J. Theberge, Oliver, British Columbia (3); I. Thompson, Canadian Forest Service, Sault Ste. Marie, Ontario (2); P. M. Youngman, Ottawa, Ontario.

I am also indebted again to the President of the Ottawa Field-Naturalists' Club Gary McNulty and the Club Council for continuing support of the journal; Chairman Ron Bedford and the Publications Committee of the OFNC for editorial encouragement and support, the finance committee for input and encouragement to speed things up, the Canadian Museum of Nature for access to its library and the facilities at the Natural Heritage Building, 1740 Pink Road, Aylmer, Quebec, and to Joyce for continuing support.

FRANCIS R. COOK Editor 